\title{
Pathogenesis of Hendra and Nipah virus infection in humans
}

\author{
Olivier Escaffre ${ }^{1}$, Viktoriya Borisevich ${ }^{1}$ and Barry Rockx ${ }^{1,2}$ \\ Departments of Pathology ${ }^{1}$ and Microbiology and Immunology ${ }^{2}$, University of Texas Medical Branch, Galveston, \\ Texas, USA
}

\begin{abstract}
Hendra virus $(\mathrm{HeV})$ and Nipah virus $(\mathrm{NiV})$ are emerging zoonotic viruses that cause severe and often lethal respiratory illness and encephalitis in humans. Henipaviruses can infect a wide range of species and human-to-human transmission has been observed for NiV. While the exact route of transmission in humans is not known, experimental infection in different animal species suggests that infection can be efficiently initiated after respiratory challenge. The limited data on histopathological changes in fatal human cases of $\mathrm{HeV}$ and $\mathrm{NiV}$ suggest that endothelial cells are an important target during the terminal stage of infection; however, it is unknown where these viruses initially establish infection and how the virus disseminates from the respiratory tract to the central nervous system and other organs. Here we review the current concepts in henipavirus pathogenesis in humans.
\end{abstract}

Key words: Hendra; Nipah; zoonotic; pathogenesis; respiratory tract; central nervous system

J Infect Dev Ctries 2013; 7(4):308-311. doi:10.3855/jidc.3648

(Received 09 April 2013 - Accepted 11 April 2013)

Copyright (C) 2013 Escaffre et al. This is an open-access article distributed under the Creative Commons Attribution License, which permits unrestricted use, distribution, and reproduction in any medium, provided the original work is properly cited.

\section{Introduction}

Hendra virus $(\mathrm{HeV})$ and Nipah virus (NiV) are two members of the genus Henipavirus (HNV; family Paramyxoviridae) that cause acute and severe respiratory illness and encephalitis in humans. $\mathrm{HeV}$ was identified in 1994 as the causative agent of an acute respiratory disease and febrile illness in horses and humans, respectively [1]. To date there have been only seven human infections with $\mathrm{HeV}$, of which four were fatal (57\%) [2]. Several outbreaks of NiV have been identified in Malaysia, Singapore, Bangladesh and India since 1998 [2]. The outbreaks in Malaysia and Singapore have primarily been associated with the development of severe febrile encephalitis with a case fatality rate of $38 \%$, while the more recent outbreaks in Bangladesh and India are associated with a higher prevalence of respiratory disease as well as a higher case fatality rate ranging from $43 \%$ to $100 \%$ in sporadic cases [2]. While the exact route of transmission in humans is not known, experimental infection in different animal species suggests that infection can be efficiently initiated after inhalation of virus particles [3-5]. Endothelial cells have been identified as an important target of infection [6]; however, it is unknown how the virus spreads to the central nervous system (CNS). Here we review the current knowledge on henipavirus pathogenesis.

\section{Transmission}

Fruit bats (Pteropodidae family) have been identified as the reservoir for $\mathrm{HNV}[7,8]$ and their geographic distribution extends beyond the outbreak sites to West Africa [9]. In addition to the isolation of $\mathrm{HeV}$ and $\mathrm{NiV}$ from these species, recent studies have identified evidence of multiple HNV-like viruses, including the isolation of Cedar virus in Australia, which is not believed to be pathogenic in humans [10]. Infected bats primarily shed HNV via the urinary route and can infect humans through involvement of intermediate amplification hosts such as horses $(\mathrm{HeV})$ and pigs (NiV outbreak in Malaysia) [11]. More recently, outbreaks of $\mathrm{NiV}$ in Bangladesh have been associated with consumption of raw date palm sap, which is believed to be contaminated with NiV from bats urinating in the sap collection jars [12]. Finally, several outbreaks of $\mathrm{NiV}$ in Bangladesh resulted in person-to-person transmission [13]. Transmission is believed to be through contact with respiratory secretions or aerosols, as the virus can be isolated from throat swabs [14].

\section{Respiratory infection}

The respiratory epithelium is an important first line of defense and actively involved in inflammation and host defense against infectious diseases. In human 
cases of $\mathrm{NiV}$ infection, $\mathrm{NiV}$ can be detected in bronchiolar epithelial cells and is shed mainly by nasopharyngeal and tracheal secretions in the early phase of the illness [14]. Patients with symptomatic respiratory tract infections were significantly more likely to transmit NiV [15]. Histological changes in the lungs of NiV cases include necrotizing alveolitis with hemorrhage, pulmonary edema, and aspiration pneumonia [16]. Multinucleated giant cells are occasionally noted in alveolar septum and alveolar spaces adjacent to necrotic areas. Intra-alveolar inflammatory cells are common. The first fatal human case of $\mathrm{HeV}$ infection resulted in severe respiratory disease in which the lungs had gross lesions of congestion hemorrhage and edema associated with histological chronic alveolitis [1]. Overall, histopathological changes of tracheal/bronchial epithelium were uncommon. In experimental animal models, viral antigen is initially detectable in the bronchi and alveoli, primarily targeting the bronchial epithelium and type II pneumocytes [3] (Figure 1A).

We recently showed that $\mathrm{HNV}$ can efficiently infect epithelial cells from the lower human respiratory tract and replicate to high titers [17]. While human-to-human transmission has been observed only in outbreaks with NiV-B, these data suggest that both $\mathrm{NiV}$ and $\mathrm{HeV}$ have the potential for human-to-human transmission through aerosols.

HNV infection of the respiratory epithelium results in the induction of inflammatory cytokines which result in the recruitment of immune cells and can progress to an Acute Respiratory Distress Syndrome (ARDS)-like disease [3]. Infection of the lower respiratory tract epithelium results in a differential inflammatory response depending on the sites of infection [17]. HNV infection of the small airway epithelium resulted in induction of key inflammatory mediators such as IL-6, 8, IL-1 $\alpha$, MCP-1, G-CSF, GM-CSF and CXCL10. Interestingly, inflammatory cytokine expression was significantly lower in trachea/bronchial epithelium. This observation is in agreement with previous reports that no inflammation is observed in the bronchial epithelium of NiV cases. Many of these key cytokines in HNV infection play a role in ARDS and are also highly expressed during infection with other virulent respiratory viruses, such as H5N1 and SARS-CoV [18-20].

\section{Viremia}

During the late stages of disease, virus replication spreads from the respiratory epithelium to the endothelium in the lungs (Figure 1B) $[3,16]$. The infection can sometimes trigger a prominent vasculitis in small vessels and capillaries as characterized by endothelial syncytium and mural necrosis [16]. Large vessels are usually not affected. HNV can then enter the bloodstream and disseminate throughout the host in either free form or by binding host leukocytes. In addition to the lungs, important target organs are the brain, spleen and kidneys, and viremia following respiratory infection can lead to multi-organ failure [1]. Interestingly, $\mathrm{HNV}$ has been shown to bind to $\mathrm{CD} 3+$ leukocytes without entry or replication of the virus [21]. In hamsters, passive transfer of NiV loaded leukocytes to naïve animals results in lethal infection [21]. In contrast in pigs, HNV can productively infect monocytes, CD6+CD8+ T lymphocytes and NK cells [22]. CD6 is a ligand for the activated leukocyte cell adhesion molecule ALCAM (CD166), which is highly expressed on the microvascular endothelial cells of the blood-air and the blood-brain barrier [22]. HNV infection of $\mathrm{T}$ cells expressing CD6 may explain the preferential tropism of $\mathrm{NiV}$ for small blood vessels of the lung and brain. It is currently unknown whether binding of HNV or infection of human leukocytes will affect the phenotype of the cells, such as increase CD6 expression, thereby preferentially homing to the CNS.

Entry into the CNS is thought to occur through two distinct pathways: anterogradely via the olfactory nerve and/or via the hematogenous route through the choroid plexus and cerebral blood vessels [23]. Infection of the CNS in humans is characterized by vasculitis, thrombosis, parenchymal necrosis, and presence of viral inclusion bodies [16]. Plaques with necrosis are found in both the gray and white matter and vasculitis, thrombosis, and parenchymal edema and inflammation are found in the vicinity of these plaques. Inflammatory cells found in the CNS primarily consist of neutrophils, macrophages, lymphocytes, and reactive microglia [16]. HNV antigen can typically be detected in neurons and neuronal processes and endothelial cells (Figure 1C). Occasionally, viral antigen is also detected in ependymal cells and rare glial cells in the white matter [16].

\section{Entry in the CNS}

HNV infection of the CNS and the development of neurological signs are associated with the disruption of the blood-brain barrier (BBB) and expression of TNF$\alpha$ and IL-1 $\beta$ [3]. These pro-inflammatory cytokines have been shown to play a role in increasing the permeability of the blood-brain barrier as well as the 
Figure 1A-D. Cell tropism of Nipah virus in lungs and brain of infected ferrets

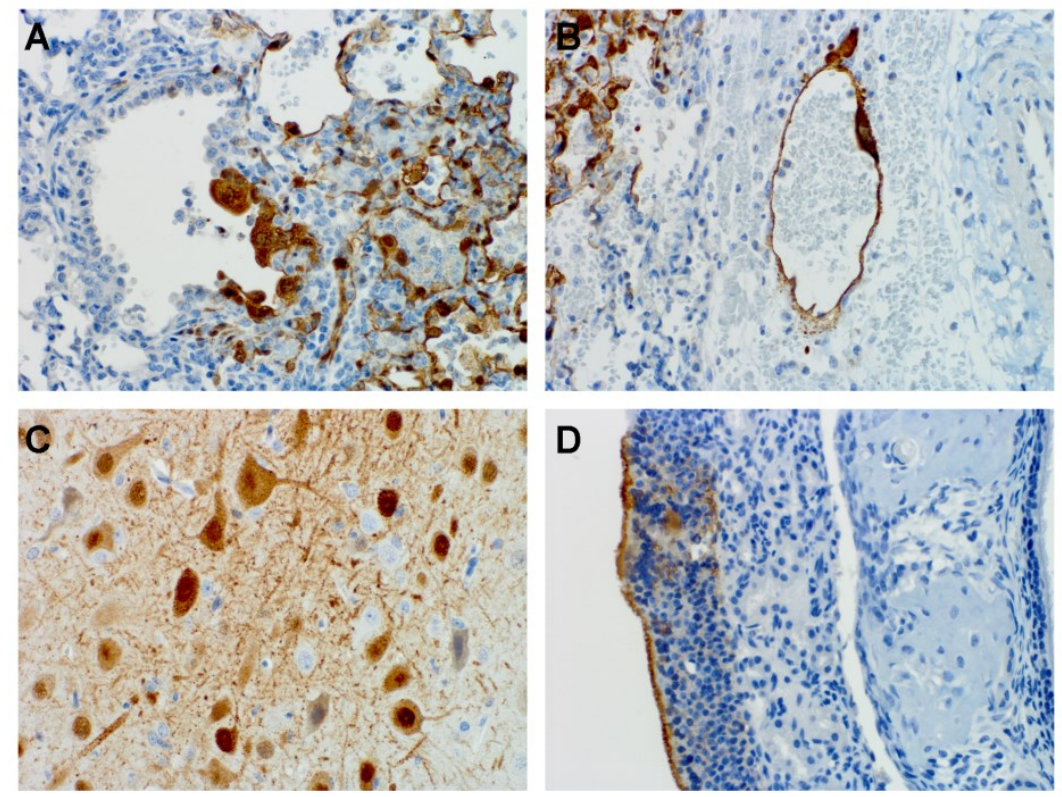

Nipah virus nucleoprotein is detected in bronchial epithelium (A) and endothelium (B) in the lungs, neurons in the brain (C) and olfactory epithelium (D) in the nasal turbinates of ferrets intranasally infected with the Malaysia strain of Nipah virus. 40X magnification.

induction of neuronal injury and death. While the source of TNF- $\alpha$ and IL-1 $\beta$ expression in the brain is currently unknown, they can be released by microglia, which are also infected by HNV. However, whether disruption of the BBB is a direct cytopathic effect of virus replication in the microvasculature or an indirect effect through expression of TNF- $\alpha$ and IL- $1 \beta$ by bystander cells such as neurons and microglia remains unclear.

Experimental studies in various animal models have shown direct entry of the CNS by HNV, through the olfactory nerve $[23,24]$. In these models, NiV infects the olfactory epithelium in the nasal turbinates (Figure 1D). NiV subsequently infects neurons extending through the cribriform plate into the olfactory bulb, providing a direct route entry into the CNS. NiV then disseminates to the olfactory tubercle and throughout the ventral cortex. It is currently unknown whether this route is also biologically relevant in human infections, since the olfactory epithelial surface is relatively large in these species compared to man.

\section{Conclusion}

The molecular mechanisms of HNV pathogenesis remain largely unknown. Several animal models are available, such as hamsters, ferrets and African green monkeys [3-5], which closely mimic the disease progression seen in human cases; however, this research is hampered by lack of reagents and sufficient animal numbers. Biologically relevant in vitro models of primary human cell cultures are also available to study the different components of HNV infection in the respiratory epithelium [17], endothelium and neurons [25] and will allow for an in-depth analysis of the host-pathogen interactions. These studies have already shown differences in host responses depending on the cell types and virus strains. The latter is of particular interest since strain variations have been observed between the NiV outbreaks in Malaysia and Bangladesh, correlating with differences in outcome of disease. Similarly, the more recent equine cases of $\mathrm{HeV}$ have been associated with a higher prevalence of neurological disease and were associated with strain variations. It is hypothesized that these genetic changes may result in differences in cell and/or tissue tropism. The recent development of reverse genetics systems for $\mathrm{NiV}$ and $\mathrm{HeV}$ will allow direct testing of this hypothesis.

Finally, a better understanding of the molecular mechanisms of HNV pathogenesis will be important for developing effective counter measures to prevent and treat infection with these often lethal viruses. 


\section{References}

1. Selvey LA, Wells RM, McCormack JG, Ansford AJ, Murray K, Rogers RJ, Lavercombe PS, Selleck P, Sheridan JW (1995) Infection of humans and horses by a newly described morbillivirus. Med J Aust 162: 642-645.

2. Rockx B, Winegar R, Freiberg AN (2012) Recent progress in henipavirus research: molecular biology, genetic diversity, animal models. Antiviral Res 95: 135-149.

3. Rockx, Brining D, Kramer J, Callison J, Ebihara H, Mansfield K, Feldmann H (2011) Clinical outcome of henipavirus infection in hamsters is determined by the route and dose of infection. J Virol 8: 7658-7671.

4. Rockx B, Bossart KN, Feldmann F, Geisbert JB, Hickey AC, Brining D, Callison J, Safronetz D, Marzi A, Kercher L, Long D, Broder CC, Feldmann H, Geisbert TW (2010) A novel model of lethal Hendra virus infection in African green monkeys and the effectiveness of ribavirin treatment. J Virol 84: 9831-9839.

5. Bossart KN, Zhu Z, Middleton D, Klippel J, Crameri G, Bingham J, McEachern JA, Green D, Hancock TJ, Chan YP, Hickey AC, Dimitrov DS, Wang LF, Broder CC (2009) A neutralizing human monoclonal antibody protects against lethal disease in a new ferret model of acute nipah virus infection. PLoS Pathog 5: e1000642.

6. Maisner A, Neufeld J, H. Weingartl H (2009) Organ- and endotheliotropism of Nipah virus infections in vivo and in vitro. Thromb Haemost 102: 1014-1023.

7. Young PL, Halpin K, Selleck PW, Field H, Gravel JL, Kelly MA, Mackenzie JS (1996) Serologic evidence for the presence in Pteropus bats of a paramyxovirus related to equine morbillivirus. Emerg Infect Dis 2: 239-240.

8. Olson JG, Rupprecht C, Rollin PE, An US, Niezgoda M, Clemins T, Walston J, Ksiazek TG (2002) Antibodies to Nipah-like virus in bats (Pteropus lylei), Cambodia. Emerg Infect Dis 8: 987-988.

9. Hayman DT, Suu-Ire R, Breed AC, McEachern JA, Wang L, Wood JL, Cunningham AA. Evidence of henipavirus infection in West African fruit bats. PLoS One 3: e2739.

10. Marsh GA, de Jong C, Barr JA, Tachedjian M, Smith C, Middleton D, Yu M, Todd S, Foord AJ, Haring V, Payne J, Robinson R, Broz I, Crameri G, Field HE, Wang LF (2012) Cedar virus: a novel Henipavirus isolated from Australian bats. PLoS Pathog 8: e1002836.

11. Luby SP, Gurley ES, Hossain MJ (2009) Transmission of human infection with Nipah virus. Clin Infect Dis 49: 17431748.

12. Rahman MA, Hossain MJ, Sultana S, Homaira N, Khan SU, Rahman M, Gurley ES, Rollin PE, Lo MK, Comer JA, Lowe L, Rota PA, Ksiazek TG, Kenah E, Sharker Y, Luby SP (2012) Date palm sap linked to Nipah virus outbreak in Bangladesh, 2008. Vector Borne Zoonotic Dis 12: 65-72.

13. Gurley ES, Montgomery JM, Hossain MJ, Bell M, Azad AK, Islam MR, Molla MA, Carroll DS, Ksiazek TG, Rota PA, Lowe L, Comer JA, Rollin P, Czub M, Grolla A, Feldmann H, Luby SP, Woodward JL, Breiman RF (2007) Person-toperson transmission of Nipah virus in a Bangladeshi community. Emerg Infect Dis 13: 1031-1037.

14. Chua KB, Lam SK, Goh KJ, Hooi PS, Ksiazek TG, Kamarulzaman A, Olson J, Tan CT (2001) The presence of Nipah virus in respiratory secretions and urine of patients during an outbreak of Nipah virus encephalitis in Malaysia. J Infect 42: 40-43.
15. Homaira N, Rahman M, Hossain MJ, Epstein JH, Sultana R, Khan MS, Podder G, Nahar K, Ahmed B, Gurley ES, Daszak P, Lipkin WI, Rollin PE, Comer JA, Ksiazek TG, Luby SP (2010) Nipah virus outbreak with person-to-person transmission in a district of Bangladesh, 2007. Epidemiol Infect 138: 1630-1636.

16. Wong KT, Shieh WJ, Kumar S, Norain K, Abdullah W, Guarner J, Goldsmith CS, Chua KB, Lam SK, Tan CT, Goh KJ, Chong HT, Jusoh R, Rollin PE, Ksiazek TG, Zaki SR; Nipah Virus Pathology Working Group (2002) Nipah virus infection: pathology and pathogenesis of an emerging paramyxoviral zoonosis. Am J Pathol 161: 2153-2167.

17. Escaffre O, Borisevich V, Carmical JR, Prusak D, Prescott J, Feldmann H, Rockx B (2013) Henipavirus Pathogenesis in Human Respiratory Epithelial Cells. J Virol 87: 3284-3294.

18. Rockx B, Baas T, Zornetzer GA, Haagmans B, Sheahan T, Frieman M, Dyer MD, Teal TH, Proll S, van den Brand J, Baric R, Katze MG (2009) Early upregulation of acute respiratory distress syndrome-associated cytokines promotes lethal disease in an aged-mouse model of severe acute respiratory syndrome coronavirus infection. J Virol 83: 70627074.

19. Puneet P, Moochhala S, Bhatia M (2005) Chemokines in acute respiratory distress syndrome. Am J Physiol Lung Cell Mol Physiol 288: L3-15.

20. Baskin CR, Bielefeldt-Ohmann H, Tumpey TM, Sabourin PJ, Long JP, García-Sastre A, Tolnay AE, Albrecht R, Pyles JA, Olson PH, Aicher LD, Rosenzweig ER, Murali-Krishna K, Clark EA, Kotur MS, Fornek JL, Proll S, Palermo RE, Sabourin CL, Katze MG (2009) Early and sustained innate immune response defines pathology and death in nonhuman primates infected by highly pathogenic influenza virus. Proc Natl Acad Sci USA 106: 3455-3460.

21. Mathieu, C., Pohl C, Szecsi J, Trajkovic-Bodennec S, Devergnas S, Raoul H, Cosset FL, Gerlier D, Wild TF, Horvat B (2011) Nipah virus uses leukocytes for efficient dissemination within a host. J Virol 85: 7863-7871.

22. Stachowiak B and Weingartl HM (2012) Nipah virus infects specific subsets of porcine peripheral blood mononuclear cells. PLoS One 7: e30855.

23. Weingartl H, Czub S, Copps J, Berhane Y, Middleton D, Marszal P, Gren J, Smith G, Ganske S, Manning L, Czub M (2005) Invasion of the central nervous system in a porcine host by nipah virus. J Virol 79: 7528-7534.

24. Munster VJ, Prescott JB, Bushmaker T, Long D, Rosenke R, Thomas T, Scott D, Fischer ER, Feldmann H, de Wit E (2012) Rapid Nipah virus entry into the central nervous system of hamsters via the olfactory route. Sci Rep 2: 736.

25. Lo MK, Miller D, Aljofan M, Mungall BA, Rollin PE, Bellini WJ, Rota PA (2010) Characterization of the antiviral and inflammatory responses against Nipah virus in endothelial cells and neurons. Virology 404: 78-88.

\section{Corresponding author}

\section{Barry Rockx}

Departments of Pathology and Microbiology \& Immunology

University of Texas Medical Branch

Galveston, Texas, USA

Telephone: 409-266-6904

Fax: 409-266-6810

Email: barockx@utmb.edu

Conflict of interests: No conflict of interests is declared. 